\title{
Opracowywanie procedur badań ultradźwiękowych techniką TOFD w odniesieniu do stref martwych i rozdzielczości przestrzennej
}

\author{
The development of an ultrasonic testing procedure \\ using TOFD technique in the context of dead zones \\ and spatial resolution
}

\section{Streszczenie}

Obserwowany w ostatnich latach wzrost zastosowań nowoczesnych technik badań ultradźwiękowych (TOFD, phased array) wiąże się z koniecznością opracowywania stosownych procedur badawczych, różniących się istotnie od typowych procedur dotyczących konwencjonalnych badań ultradźwiękowych. Z tego względu w pracy opisano najistotniejsze zagadnienia, które powinny zostać przeanalizowane i uwzględnione na etapie przygotowania procedury badania ultradźwiękowego techniką czasu przejścia wiązki dyfrakcyjnej TOFD. Szczególną uwagę zwrócono na analizę wielkości stref martwych TOFD oraz zmian rozdzielczości przestrzennej na grubości badanego złącza, a także doprecyzowanie zasad oceny wskazań niemierzalnych w kierunku wysokości.

Słowa kluczowe: badania ultradźwiękowe spoin; technika TOFD; procedura badania
Abstract

The increase in the use of advanced ultrasonic testing techniques such as TOFD and Phased Array, observed in recent years is connected with the necessity of development of appropriate testing procedures, differing significantly from typical procedures for conventional ultrasound examinations. For this reason, the paper describes the most important issues that should be analyzed and taken into account at the stage of preparation of the ultrasonic examination procedure with the time of flight diffraction TOFD technic. Particular attention has been paid to the size of TOFD dead zones and changes in spatial resolution on the thickness of the joint tested, as well as the clarification of the principles for the assessment of unmeasurable in the direction of joint thickness indications.

Keywords: ultrasonic testing of welds; TOFD; NDT procedures

\begin{abstract}
Wstęp
Badania ultradźwiękowe techniką czasu przejścia wiązki dyfrakcyjnej TOFD są stosowane $\mathrm{w}$ polskim przemyśle już dwie dekady [1]. Pierwsze zastosowania ograniczały się jednak w zasadzie wyłącznie do badań spoin obwodowych rurociągów, stąd ilość wykonywanych badań oraz liczba personelu pracującego przy projektowaniu, wykonywaniu i ocenie badań była niewielka. Wraz z dynamicznym rozwojem, dostępnością i spadkiem cen sprzętu do badań TOFD przejawiającym się w stosunkowo tanich, przenośnych defektoskopach do badań UT+TOFD, a także dużym wyborem niewielkich, poręcznych skanerów umożliwiających badanie nawet krótkich odcinków złączy doczołowych, możemy spodziewać się znacznego poszerzenia obszaru zastosowań techniki TOFD sukcesywnie zastępujących - wraz z techniką phased array
\end{abstract}

- dotychczasowy obszar stosowania konwencjonalnych badań ultradźwiękowych. Sprzyja temu zarówno pełna normalizacja obydwu technik (w aspekcie wykonawstwa oraz oceny wskazań), jak i ich główna zaleta w postaci wysokiej wiarygodności dzięki pełnemu zapisowi cyfrowemu wyniku badania a także znacznie wyższej wykrywalności w stosunku do badań UT.

Poszerzeniu obszaru zastosowań techniki TOFD sprzyja także znaczna ilość publikacji ukazujących się w ostatnich latach w Polsce, pozwalająca na łatwe zapoznanie z najistotniejszymi aspektami badań TOFD przez grono personelu badań NDT, inspektorów, spawalników, aż po klientów zamawiających konstrukcje spawane i poszukujących wiarygodnych metod potwierdzenia jakości wykonanych złączy spawanych [2:6].

Mgr inż. Rafał Kaczmarek - Politechnika Częstochowska, dr inż. Karol Kaczmarek - Instytut Spawalnictwa.

Autor korespondencyjny/Corresponding author: rafal.kaczmarek133@gmail.com 
Z tego względu, wraz ze zwiększeniem obszaru zastosowań badań TOFD w przemyśle, znacznie poszerza się grono personelu NDT opracowującego procedury badań tą techniką. Ponieważ jest to zadanie różniące się istotnie od przygotowania typowych procedur dotyczących konwencjonalnych badań ultradźwiękowych, z tego względu w niniejszym artykule autorzy starali się przybliżyć podstawowe zagadnienia, które powinny zostać uwzględnione w tym procesie.

\section{Zalety i ograniczenia techniki TOFD}

Zastosowanie badań ultradźwiękowych techniką TOFD wykazuje wiele zalet $\mathrm{w}$ porównaniu $\mathrm{z}$ innymi metodami nieniszczących badań objętościowych. Do podstawowych zalet można zaliczyć relatywną łatwość przeprowadzenia badań, powiązaną z brakiem istotnych zagrożeń dla personelu badającego i osób postronnych, wysoką wykrywalność, w szczególności nieciągłości płaskich, mały wpływ orientacji nieciągłości na jej wykrywalność oraz - w wielu przypadkach - możliwość określenia rzeczywistych wymiarów nieciągłości, i co się z tym wiąże, stosowania wymiarowych kryteriów akceptacji.

Niestety, wymienione wyżej zalety limitowane są wieloma czynnikami nierozłącznie związanymi z techniką TOFD. Pierwszą grupę czynników stanowią ograniczenia w zastosowaniu techniki TOFD. Wykorzystywane w niej sygnały dyfrakcyjne wykazują niską amplitudę, istotnym problemem staje się zatem poziom szumu, zarówno elektronicznego, jak i strukturalnego, utrudniający lub uniemożliwiający badanie materiałów gruboziarnistych, takich jak odlewy i złącza ze stali austenitycznych. Złożona geometria złącza stanowi bardzo istotne ograniczenie dla przeprowadzenia badania, wynikające $z$ trudności w opracowaniu procedury badania, potrzeby stosowania wyspecjalizowanych skanerów i utrudnionej analizy wyników. Z wyżej wymienionych powodów technika TOFD stosowana jest zasadniczo do badania złączy o prostej geometrii wykonanych z materiałów drobnoziarnistych.

Drugim ograniczeniem techniki TOFD są trudności dotyczące wykrywalności, trudności w zakresie interpretacji oraz wymiarowania wskazań związane z nakładaniem się sygnałów ultradźwiękowych odbieranych przez głowicę. Pierwszym tego typu zjawiskiem jest tworzenie się stref martwych. W technice TOFD tworzą się dwie strefy martwe: od powierzchni badania oraz od powierzchni przeciwległej. Są one wynikiem nakładania się sygnałów odpowiednio fali podpowierzchniowej lub fali odbitej na ewentualne sygnały dyfrakcyjne pochodzące od wierzchołków nieciągłości. Może to prowadzić do trudności z wykryciem nieciągłości. Jeśli nieciągłość zostaje wykryta, to występuje poważna trudność, a często zupełny brak możliwości jej wymiarowania, i co się z tym wiąże, również oceny jej akceptowalności.

W przypadku nieciągłości wewnętrznych o niewielkiej wysokości może dojść do nałożenia się sygnałów od górnego i dolnego wierzchołka nieciągłości. Do nałożenia sygnałów dochodzi wówczas, gdy różnica w czasie przejścia pomiędzy impulsami jest krótsza od czasu trwania impulsu ultradźwiękowego. Nałożenie sygnałów odebranych przez głowicę uniemożliwia określenie wysokości nieciągłości. W efekcie niezgodności tego rodzaju tworzą wskazania niemierzalne w kierunku wysokości. Graniczny wymiar, poniżej którego dochodzi do połączenia sygnałów pochodzących od górnego i dolnego wierzchołka nieciągłości nazywany jest rozdzielczością przestrzenną. Nieciągłość o mniejszej wysokości od wartości rozdzielczości przestrzennej wygeneruje wskazanie $\mathrm{w}$ postaci sygnału będącego wynikiem nałożenia sygnałów dyfrakcyjnych od górnej i dolnej krawędzi nieciągłości.
Wskazanie takie traktowane jest jako niemierzalne po wysokości. Efektem braku możliwości określenia wysokości nieciągłości w oparciu o jej wskazanie są trudności w ocenie akceptowalności wskazania.

PN-EN ISO 10863, określająca zasady badania techniką TOFD złączy spawanych, wymaga stosowania procedur badania $w$ najwyższych poziomach badania (C i D), nie określając jednak precyzyjnie wymagań dotyczących informacji, które powinny być zawarte w procedurze [7]. Wytyczne dotyczące opracowywania procedur badawczych, sformułowane w sposób ogólny można odnaleźć w PN-EN ISO 16810 [8]. W praktyce stosowania techniki TOFD pojawia się jednak wiele specyficznych problemów dotyczących zarówno wykonania badania, jak i oceny wyników, które powinny być rozważone na etapie opracowywania procedur badania. Jednym z tych zagadnień jest sposób postępowania ze wskazaniami, które nie są możliwe do jednoznacznego zwymiarowania. PN-EN ISO 15626 nie podaje wprost sposobu postępowania w przypadku wykrycia tego rodzaju wskazań problematycznych, które nie mogą być jednoznacznie ocenione z powodu występowania w strefie martwej czy też wskazań niemierzalnych po wysokości [9]. Wskazówką podawaną przez normę PN-EN ISO 10863 jest wymóg oceny wskazania zgodnie z założeniem najgorszego scenariusza. Jednocześnie norma stwierdza, że wskazania, które nie mogą być jednoznacznie sklasyfikowane, mogą wymagać dodatkowych badań. Można więc uznać, że dokładny sposób postępowania w przypadku wykrycia tego rodzaju wskazań powinien być ostatecznie określony w procedurze badania. W dalszej części artykułu podano rozważania dotyczące tego zagadnienia.

\section{Strefy martwe TOFD}

W badaniach TOFD występują strefy martwe od powierzchni skanowania oraz powierzchni przeciwległej badanego elementu. Strefa martwa od powierzchni skanowania jest spowodowana występowaniem sygnału fali podpowierzchniowej, czyli fali ultradźwiękowej podłużnej rozprzestrzeniającej się pod powierzchnią badania. Sygnały dyfrakcyjne od nieciągłości występujących płytko pod powierzchnią skanowania nakładają się na sygnał fali podpowierzchniowej. W efekcie mogą pozostać niewykryte. Jeśli natomiast zostaną wykryte, to występuje poważna trudność z ich interpretacją i wymiarowaniem. Zgodnie z PN-EN ISO 16828 , wielkość strefy martwej od powierzchni skanowania $\mathrm{D}_{\mathrm{ds}}$ określona jest następującą zależnością [10]:

$$
D_{d s}=\sqrt{\frac{c^{2} t_{p}^{2}}{4}-s c t_{p}}
$$

gdzie:

c - prędkość dźwięku [m/s],

$t_{p}$ - czas trwania sygnału ultradźwiękowego [ $\left.\mu \mathrm{s}\right]$,

$\mathrm{s}$ - połowa odległości pomiędzy środkami głowic [mm].

Analogicznie, w przypadku strefy martwej od powierzchni przeciwległej $D_{d w}$, sygnały dyfrakcyjne od nieciągłości mogą zostać zasłonięte przez sygnał fali odbitej. Zgodnie z PN-EN ISO 16828 wielkość strefy martwej od powierzchni przeciwległej może zostać obliczona z wzoru:

$$
D_{d w}=\sqrt{\frac{c^{2}\left(t_{w}+t_{p}\right)^{2}}{4}-s^{2}-W}
$$

gdzie:

c - prędkość dźwięku [m/s],

$t_{w}$ - czas przejścia wiązki odbitej od powierzchni przeciwległej $[\mu s]$,

W - grubość ścianki badanego elementu [mm]. 
Fakt występowania stref martwych powoduje ograniczenie efektywnego obszaru badanego. Strefy martwe zmniejszają wykrywalność nieciągłości występujących blisko powierzchni badanego elementu oraz utrudniają wymiarowanie nieciągłości w tych obszarach.

$\mathrm{Na}$ rysunku 1 przedstawiono skany próbki odniesienia TOFD o grubości $12 \mathrm{~mm}$, zawierającej trzy nieciągłości referencyjne. Nieciągłość nr 2 to nacięcie o głębokości $1 \mathrm{~mm}$ wykonane od powierzchni przeciwległej, natomiast nieciągłość nr 3 to otwór cylindryczny o średnicy $2 \mathrm{~mm}$ wykonany na głębokości $4 \mathrm{~mm}$ pod powierzchnią skanowania. Nieciągłości te służą do sprawdzenia wykrywalności nieciągłości usytuowanych w obszarach stref martwych. Kolejne skany przedstawiają wyniki badania TOFD z następującymi parametrami badania:

- częstotliwość $5 \mathrm{MHz}$, wymiar przetwornika $6 \mathrm{~mm}$, kąt 70 (rys. 1a),

- częstotliwość $10 \mathrm{MHz}$, wymiar przetwornika 3 mm, kąt 70 (rys. 1b),

- częstotliwość $15 \mathrm{MHz}$, wymiar przetwornika $3 \mathrm{~mm}$, kąt 70 (rys. 1c).
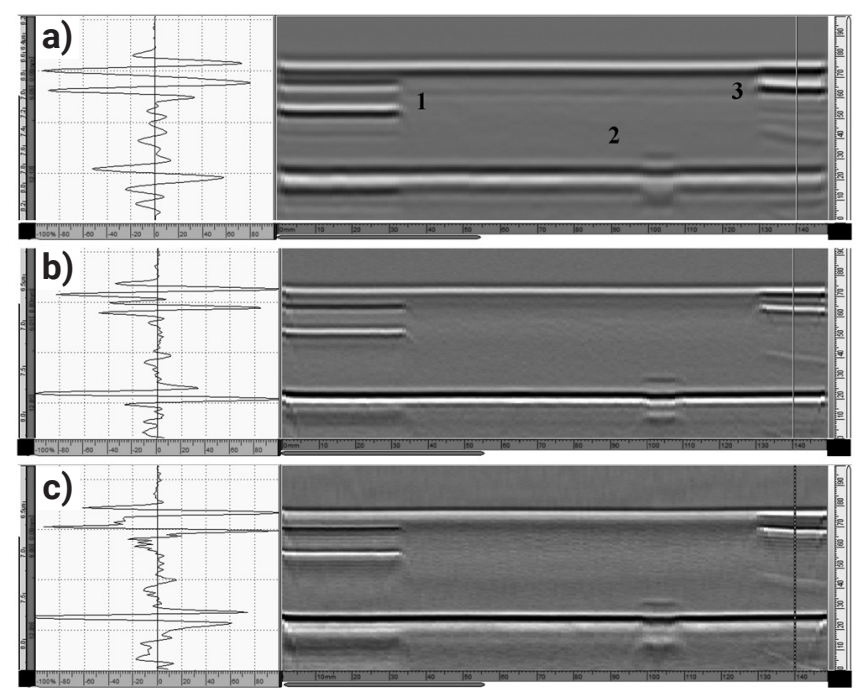

Rys. 1. Wyniki badania próbki odniesienia o grubości $t=12 \mathrm{~mm}$ przy różnych parametrach głowic TOFD

Fig. 1. The results of the tests of a reference block with a thickness of $\mathrm{t}=12 \mathrm{~mm}$ and various probe parameters

Spadek częstotliwości badania powoduje wzrost wielkości stref martwych. Można to zaobserwować szczególnie na przykładzie strefy martwej przy powierzchni skanowania, ze względu na znacznie większą wysokość tej strefy w stosunku do strefy martwej przy powierzchni przeciwległej. W przypadku badania głowicami o częstotliwości $5 \mathrm{MHz}$ sygnał od górnej powierzchni jest całkowicie nałożony na sygnał fali podpowierzchniowej. Z kolei dla częstotliwości $10 \mathrm{MHz}$ i $15 \mathrm{MHz}$ wnikliwa obserwacja zmian na zobrazowaniach typu A i B, powiązana z porównaniem wyglądu wskazania od fali podpowierzchniowej w miejscu występowania nieciągłości z miejscami, gdzie ona nie występuje, umożliwia wykrycie sygnału od górnej powierzchni otworu. Sygnał ten jest możliwy do zauważenia, jednak jego interferencja z sygnałem fali podpowierzchniowej utrudnia lub uniemożliwia precyzyjne ustawienie kursora pomiarowego i dokładny pomiar wysokości wskazania.

Przy opracowywaniu procedury badania należy zatem określić wielkości stref martwych i dokładnie przeanalizować możliwe konsekwencje niewykrycia niewielkich nieciągłości znajdujących się w tych obszarach. W uzasadnionych przypadkach może być wskazane zaplanowanie dodatkowych badań uzupełniających, mających na celu pokrycie obszarów stref martwych TOFD.
Korzystając z faktu występowania dużych różnic w wielkości stref martwych od powierzchni skanowania oraz od powierzchni przeciwległej, możliwa jest znaczna poprawa wykrywalności poprzez wykonanie dodatkowego skanowania od powierzchni przeciwległej złącza. Na rysunku 2 zaprezentowano obrazy TOFD uzyskane w badaniach wykonanych z powierzchni od strony lica i grani spoiny. Łatwo zauważyć, że trudny do wykrycia i jednoznacznej klasyfikacji sygnał 1 znajdujący się w strefie martwej przy powierzchni skanowania (rys. 2a) staje się łatwy do interpretacji na obrazie TOFD uzyskanym w badaniu od strony grani spoiny (rys. 2b).

W przypadku badania odpowiedzialnych elementów, w których dąży się do wykrycia wszystkich nieciągłości w badanym złączu, korzystne jest wykonanie badań TOFD z obydwu powierzchni złącza (od powierzchni lica i grani, o ile istnieje dostęp). Zwiększa ono zarówno wykrywalność, jak i możliwości interpretacji wskazań od nieciągłości położonych blisko powierzchni lica. Natomiast w przypadkach, w których badaniom TOFD poddaje się tylko pewien procent długości złączy, badania z przeciwnej strony mogą być ograniczone do wybranych odcinków. Służą one wówczas do weryfikacji uprzednio wykrytych wskazań trudnych do interpretacji.

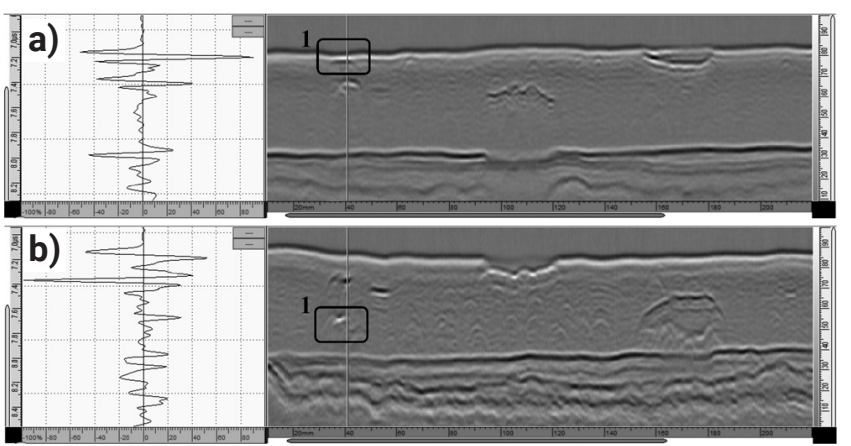

Rys. 2. Wynik badania TOFD złączą o grubości $12 \mathrm{~mm}$ skanowanego od strony lica (a) i grani (b) spoiny (częstotliwość $10 \mathrm{MHz}$, średnica przetwornika $3 \mathrm{~mm}$, kąt $70^{\circ}$ )

Fig. 2. The result of TOFD of welded joint, thickness of $12 \mathrm{~mm}$, scanned from the face side (a) and rut (b) of the weld (frequency $10 \mathrm{MHz}$, diameter of the transducer $3 \mathrm{~mm}$, angle $70^{\circ}$ )

\section{Rozdzielczość przestrzenna}

Rozdzielczością przestrzenną badania TOFD nazywana jest najmniejsza wysokość nieciągłości, przy której nie następuje nakładanie się sygnałów górnej i dolnej dyfrakcji. Rozdzielczość przestrzenna R na głębokości d opisana jest następującą zależnością:

$$
R=\sqrt{\frac{c^{2}\left(t_{d}+t_{p}\right)^{2}}{4}-s^{2}-d}
$$

gdzie:

$t_{d}$ - czas przejścia wiązki dla głębokości d [ $\left.\mu s\right]$,

d - głębokość w stosunku do powierzchni skanowania [mm].

Większość zmiennych w powyższym wzorze posiada jednoznacznie określoną wartość dla założonej konfiguracji badania. Wyjątkiem jest czas trwania sygnału ultradźwiękowego. Wartość tego parametru uzależniona jest od arbitralnie przyjętego kryterium spadku decybelowego, dla którego wyznaczana jest wartość czasu trwania impulsu. Wynika stąd, że wyznaczona w obliczeniach wartość rozdzielczości badania będzie bezpośrednią konsekwencją przyjętego arbitralnie kryterium spadku decybelowego, dla którego wyznaczana jest wartość czasu trwania impulsu. Przykładowe wartości czasu trwania impulsu ultradźwiękowego, dla różnych kryteriów spadku decybelowego podano w tablicy I. 
Tablica I. Wpływ wybranego kryterium spadku amplitudy na czas trwania impulsu ultradźwiękowego dla przetworników o częstotliwości $10 \mathrm{MHz}$ stosowanych w dalszych badaniach

Table I. Example of impact of the selected amplitude drop criterion on the duration of the ultrasonic pulse for $10 \mathrm{MHz}$ transducers used in further studies

\begin{tabular}{|c|c|c|c|}
\hline \multirow{2}{*}{$\begin{array}{c}\text { Częstotliwość } \\
\text { przetwornika }\end{array}$} & \multicolumn{3}{|c|}{ Czas trwania impulsu dla kryterium } \\
\cline { 2 - 4 } & $\mathbf{- 1 4} \mathbf{d B}$ & $\mathbf{- 2 0} \mathbf{d B}$ & $\mathbf{- 4 0} \mathbf{~ d B}$ \\
\hline $10 \mathrm{MHz}$ & $\mathbf{0 , 1 2 9 \mu \mathrm { s }}$ & $0,233 \mu \mathrm{s}$ & $0,364 \mu \mathrm{s}$ \\
\hline
\end{tabular}

Przedstawione w tablicy I wyniki dowodzą, że wybór kryterium jest więc krytycznie ważny. PN-EN ISO 16828 określa, że jako kryterium należy traktować warunek -20 dB (10\% amplitudy). Znając wartości parametrów badania możliwe jest określenie rozdzielczości przestrzennej. Na rysunku 3 przedstawiono wykres rozdzielczości przestrzennej od głębokości zalegania nieciągłości w badaniu złącza o grubości $10 \mathrm{~mm}$.

W oparciu o uzyskany wykres łatwo zauważyć, że największe i najbardziej niekorzystne wartości rozdzielczości przestrzennej występują w przypadku wskazań położonych płytko pod powierzchnią skanowania. Ze wzrostem głębokości spada wartość rozdzielczości przestrzennej $R$, która najkorzystniejsze wartości z punktu widzenia wymiarowania wysokości wskazań przyjmuje w pobliżu powierzchni przeciwległej.

Na rysunku 4 umieszczono skan złącza spawanego o grubości $12 \mathrm{~mm}$ zawierający wskazania trudne do interpretacji i jednoznacznego zwymiarowania ze względu na niekorzystną

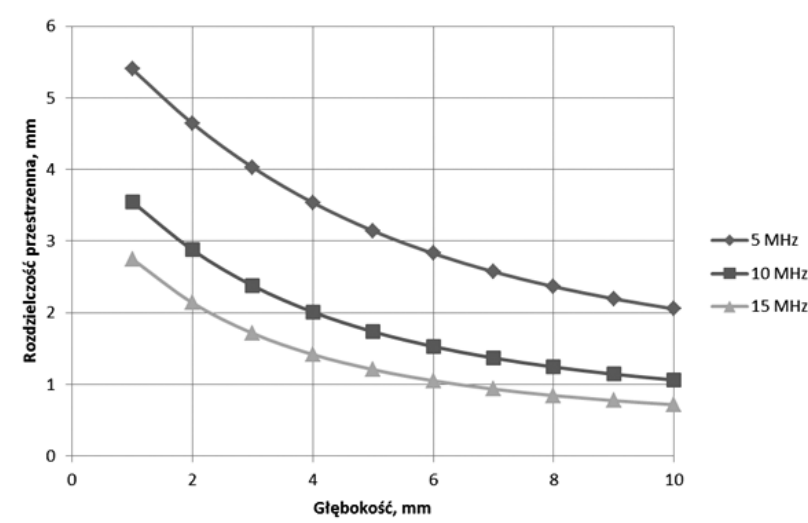

Rys. 3. Rozdzielczość przestrzenna w funkcji głębokości na przykładzie badania złącza o grubości $10 \mathrm{~mm}$ przy częstotliwości głowic równej $5 \mathrm{MHz}, 10 \mathrm{MHz}$ i $15 \mathrm{MHz}$, kąt wprowadzenia wiązki 70

Fig. 3. Value of spatial resolution as a function of depth on the example of a joint test with a thickness of $10 \mathrm{~mm}$ at a frequency of $5 \mathrm{MHz}, 10 \mathrm{MHz}$ and $15 \mathrm{MHz}$, probe angle $70^{\circ}$
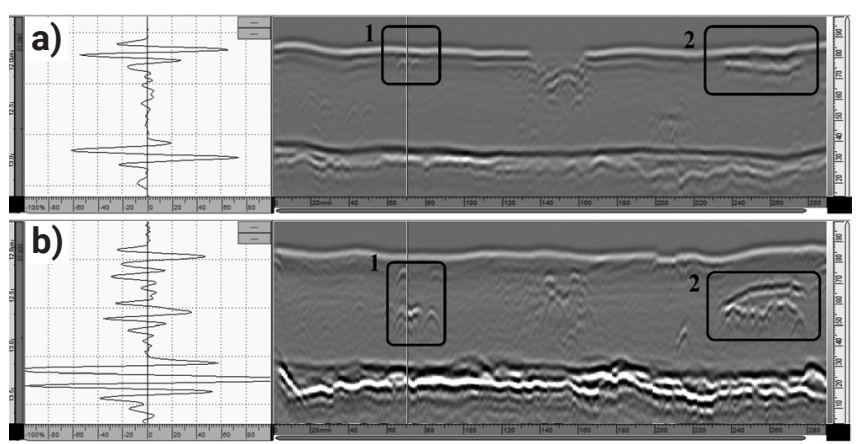

Rys. 4. Wyniki badania złącza o grubości $12 \mathrm{~mm}$ z powierzchni od strony lica i grani spoiny. Na skanie od strony lica (a) wskazania nr 1 i 2 położone w strefie o niskiej rozdzielczości są trudne do klasyfikacji i zwymiarowania

Fig. 4. The results of the test of welded joint with a thickness of $12 \mathrm{~mm}$, from the face side and the root side surface of the weld. On the scan from the face (a), indications 1 and 2 located in the low-resolution zone are difficult to classify and measure wartość rozdzielczości przestrzennej na głębokości, na której występują (rys. 4a). Wskazania nr 1 i 2 są zlokalizowane tuż pod falą podpowierzchniową. Dopiero wykonanie badania uzupełniającego, przeprowadzonego przy tych samych parametrach, jednakże z przeciwnej powierzchni (od strony grani) pozwala na jednoznaczne sklasyfikowanie i zwymiarowanie wskazań (rys. 4b). Wskazanie nr 1 może na tej podstawie zostać sklasyfikowane jako niemierzalne po wysokości w warunkach, kiedy na głębokości jego zalegania występuje korzystna wartość rozdzielczości przestrzennej, co wskazuje na niewielką wysokość wykrytej nieciągłości. Wskazanie nr 2 wykazuje natomiast wyraźne sygnały od górnej i dolnej krawędzi, dzięki czemu daje możliwość precyzyjnego zwymiarowania wysokości.

\section{Procedura badania TOFD}

Zgodnie z PN-EN ISO 10863, która stanowi podstawową normę badania w przypadku badania techniką TOFD złączy spawanych, dla poziomów badania C i D wymagane jest opracowanie procedury badania. Norma nie określa jednakże jednoznacznie jakie informacje powinny zostać określone w procedurze. Norma powołuje się na PN-EN ISO 16828, która z kolei w zakresie wymagań dotyczących procedury badania, powołuje się na PN-EN ISO 16810. PN-EN ISO 16810 określa zakres informacji, które powinny być określone w procedurze badania metodą ultradźwiękową. Do informacji tych należą:

- opis badanego wyrobu,

- odwołania do innych dokumentów,

- kwalifikacje i certyfikacje personelu,

- stan obiektu badania,

- obszary badania,

- przygotowanie powierzchni badania,

- środek sprzęgający,

- opis sprzętu wykorzystywanego w badaniach,

- warunki otoczenia,

- ustawienia i kalibracje,

- plan badania/skanowania,

- opis i kolejność czynności wykonywanych podczas badania,

- poziomy oceny i rejestracji,

- wymagania dotyczące charakteryzowania niezgodności,

- kryteria akceptacji,

- wymagania dotyczące raportowania wyników badań [8].

Warto zwrócić uwagę na fakt, że wymagania te są często mniej lub bardziej precyzyjnie uszczegółowione w innych normach, takich jak PN-EN ISO 10863 i PN-EN ISO 15626 w przypadku badania złączy spawanych techniką TOFD. Niezależnie od tego, dla uzyskania wysokiej wiarygodności i powtarzalności wyników badań warunki te wymagają w wielu przypadkach ostatecznego uszczegółowienia w procedurze badania.

Pierwszym istotnym w tym kontekście zagadnieniem są wymagania dotyczące szeroko pojętych ustawień i kalibracji sprzętu. W technice TOFD wymaga to zaprojektowania i wykonania próbki odniesienia. Kolejnym krokiem jest wybór parametrów stosowanej konfiguracji TOFD oraz opracowanie planu badania (tzw. scan plan-u) wraz z weryfikacją wykrywalności na próbkach odniesienia.

Przykładowy plan skanowania dla złącza o grubości $120 \mathrm{~mm}$ ukosowanego na $X$ przedstawiono na rysunku 5 . Założono w nim podział na trzy strefy badania $(0 \div 40$, $40 \div 80,80 \div 120 \mathrm{~mm}$ ) i wykorzystanie trzech konfiguracji TOFD (TOFD1, TOFD2 i TOFD3). Skanowanie przy użyciu konfiguracji odpowiedzialnej za wykrywanie nieciągłości położonych na największej głębokości jest wykonywane dwukrotnie z przesunięciem w stosunku do osi spoiny (TOFD3A i TOFD3B). 


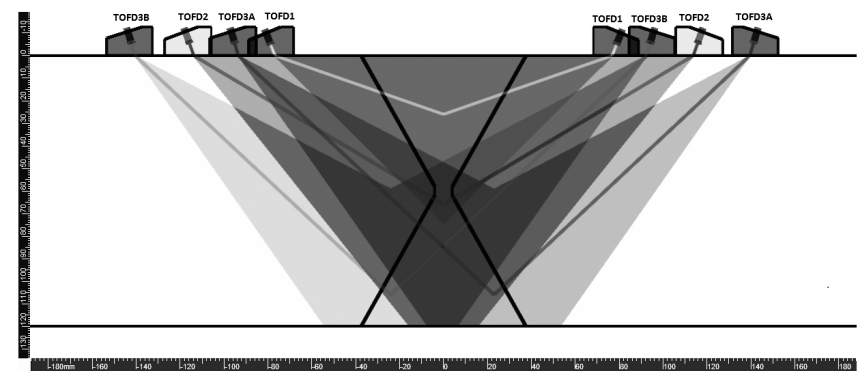

Rys. 5. Plan skanowania dla złącza o grubości $120 \mathrm{~mm}$ ze spoiną dwustronną ukosowaną na $\mathrm{X}$ wykonany w oprogramowaniu NDTSetupBuilder

Fig. 5. Scanplan for $120 \mathrm{~mm}$ joint with double side, X-type weld beveled obtained in NDTSetupBuilder software

Norma nie określa jednoznacznych wymagań dotyczących weryfikacja ustawień sprzętowych. Wszystkie te zagadnienia powinny być uszczegółowione przez osobę opracowującą procedurę badania w taki sposób, żeby uzyskać wysoką wiarygodność i powtarzalność wyników badania, przy jednoczesnym uwzględnieniu aspektów praktycznych związanych z wykonywanym badaniem. Na tym etapie należy szczegółowo przeanalizować wielkość stref martwych dla zastosowanej konfiguracji badawczej oraz potwierdzić wykrywalność nieciągłości w strefach przypowierzchniowych przy pomocy specjalnie wykonanych nieciągłości na próbce odniesienia.

Drugim zagadnieniem, które powinno być brane pod uwagę na etapie opracowywania procedury badania jest uszczegółowienie zasad klasyfikacji i oceny wykrytych wskazań z punktu widzenia rozdzielczości przestrzennej dla zastosowanej konfiguracji TOFD. Poniżej przeanalizowane zostaną kryteria akceptacji podane w PN-EN ISO 15626 dla poziomu akceptacji 1 (odpowiadającego poziomowi jakości B) i grubości złącza równej $\mathrm{t}=10 \mathrm{~mm}$. Wskazania wewnętrzne o długości nieprzekraczającej 7,5 mm są akceptowalne do wysokości $2 \mathrm{~mm}$, natomiast wychodzące na powierzchnię do wysokości $1,5 \mathrm{~mm}$. Wskazania o długości powyżej 7,5 mm są akceptowalne, jeśli ich wysokość nie przekracza $1 \mathrm{~mm}$. Wynika stąd, że w celu oceny akceptowalności wskazań istnieje potrzeba pomiaru ich wysokości na poziomie $1 \mathrm{~mm}$. Z kolei rysunek 3 przedstawiający wykres rozdzielczości przestrzennej od głębokości obrazuje, iż możliwość po- miaru wysokości wskazania o takiej wartości jest możliwa wyłącznie na głębokości 7 $\div 10 \mathrm{~mm}$ (zakładając wykonanie badania zgodnie z wymaganiami ISO 10863, tzn. przy użyciu głowic o częstotliwości $15 \mathrm{MHz}$ ). Zatem nieciągłości nieakceptowalne o wysokości nieznacznie przekraczające $1 \mathrm{~mm}$ zalegające na głębokościach mniejszych (tzn. $0 \div 7 \mathrm{~mm}$ ) będą zobrazowane w postaci tzw. wskazań „nitkowych”, niemierzalnych po wysokości (rys. 6).

Z tego względu w procedurze badania powinny zostać zawarte jednoznaczne zalecenia dotyczące oceny wskazań niemierzalnych po wysokości oparte na analizie rozdzielczości przestrzennej na głębokości badanego złącza dla zastosowanej konfiguracji badawczej (częstotliwości, odległości między środkami głowic PCS itd.). Na jej podstawie należy wyznaczyć dwie strefy ocenianego skanu:

- pierwsza strefa, w której wartość rozdzielczości przestrzennej jest większa od dopuszczalnej wysokości wskazania. Strefa ta rozpoczyna się od powierzchni skanowania i kończy na głębokości, na której rozdzielczość przestrzenna zrównuje się z dopuszczalną wysokością wskazania. Wskazanie niemierzalne po wysokości występujące w tej strefie może pochodzić zarówno od nieciągłości o akceptowalnej wysokości (poniżej $1 \mathrm{~mm}$ w przytoczonym powyżej przypadku), jak i od nieciągłości, której wysokość przekracza wymiar dopuszczalny, lecz jest na tyle niewielka, że nie powoduje powstania dwóch oddzielnych wskazań dyfrakcyjnych od górnego i dolnego wierzchołka nieciągłości. Wskazania niemierzalne po wysokości występujące $w$ tej strefie powinny być ocenione jako nieakceptowalne do weryfikacji. W przypadku, jeżeli istnieje możliwość przeprowadzenia badania rozstrzygającego, może ono być podstawą do ostatecznego zaakceptowania takowego wskazania pod warunkiem, iż jednoznacznie potwierdzi jego akceptowalność. Badanie to powinno zostać przeprowadzone metodą o wykrywalności zbliżonej do badań TOFD. Stąd też preferowane techniki to badania phased array lub TOFD z parametrami dopasowanymi do wykrycia i oceny danego wskazania. Zastosowanie konwencjonalnych badań ultradźwiękowych bądź radiograficznych może prowadzić do braku wykrycia weryfikowanego wskazania (np. przyklejenia brzegowe o orientacji niekorzystnej $\mathrm{w}$ stosunku do promieniowania w badaniach RT lub zastosowanego kąta wprowadzenia wiązki w badaniach UT).

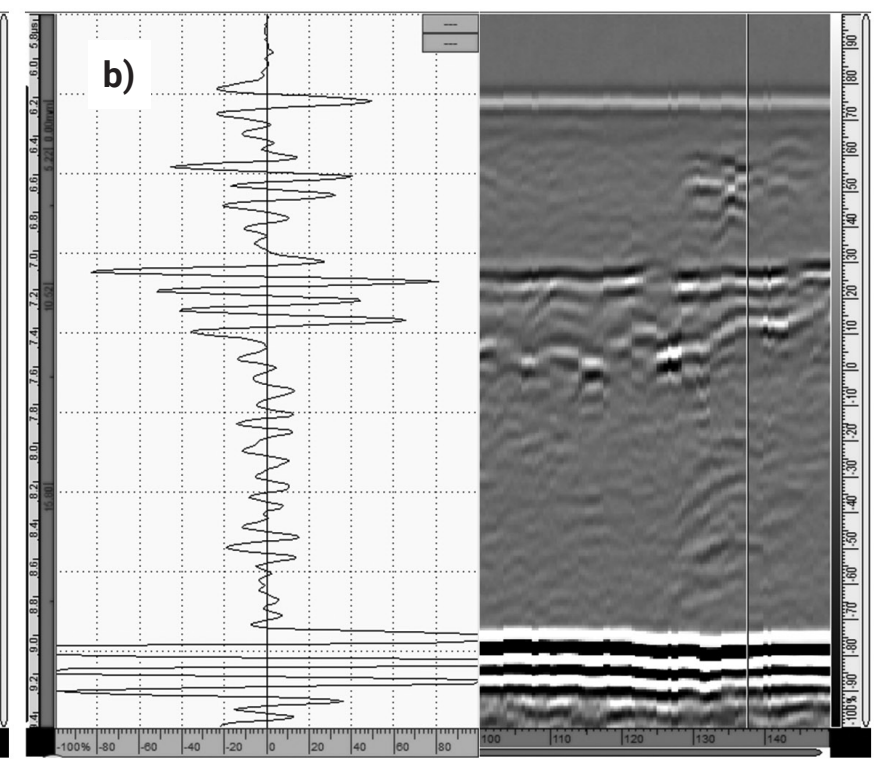

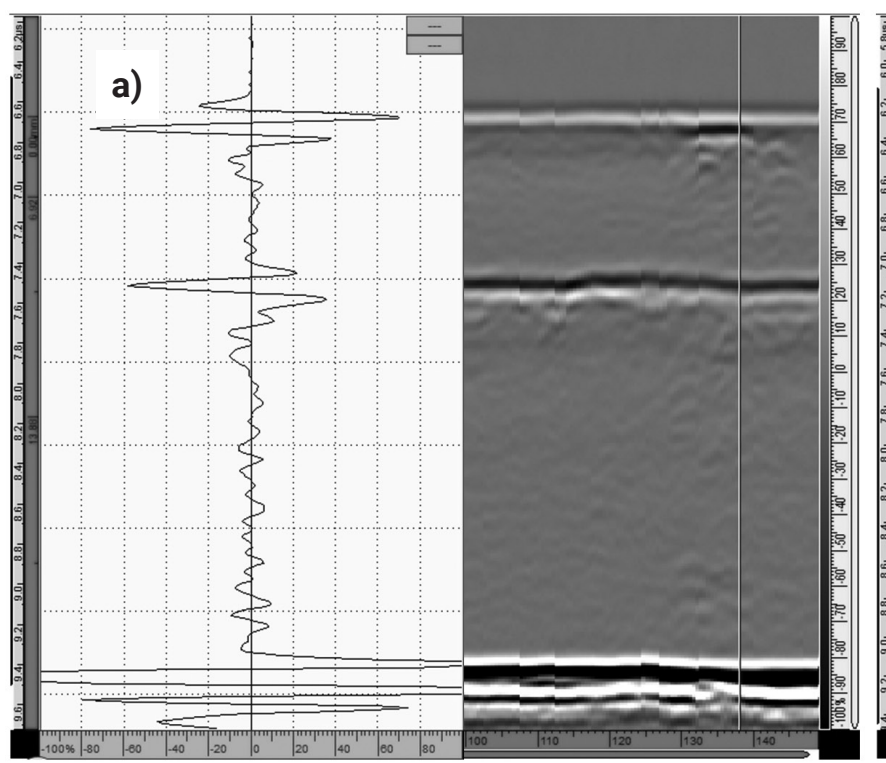

strony lica (a). Badanie uzupełniające od strony grani spoiny

Rys. 6. Przykład wskazania niemierzalnego po wysokości w badaniu od strony lica (a). Ba
(b) umożliwia lepszą interpretację wskazania dzięki korzystniejszej rozdzielczości przestrzenne

Fig. 6. An example of an unmeasurable indication when tested from the face side of a weld (a). Supplementary examination from the root side of the weld (b) enables better interpretation due to the more favorable spatial resolution 
- druga strefa, w której wartość rozdzielczości przestrzennej jest mniejsza od dopuszczalnej wysokości wskazania. Występuje ona przy powierzchni przeciwległej do powierzchni skanowania. Wskazania niemierzalne po wysokości występujące w tej strefie pochodzą wyłącznie od nieciągłości o wysokości mniejszej od wymiaru dopuszczalnego, stąd też wszystkie są akceptowalne na tym etapie oceny (ze względu na ich wysokość). Jeżeli takowe wskazania występują w dużej ilości na danym odcinku skanu, wówczas na kolejnym etapie oceny wliczają się one do sumarycznej długości wskazań i w pewnych warunkach mogą decydować o braku akceptacji tegoż odcinka.

Zaproponowany sposób postępowania ze wskazaniami niemierzalnymi po wysokości jest zgodny z zasadą „najgorszego scenariusza", wskazującą na interpretację wskazań niejednoznacznych w sposób najbardziej rygorystyczny, biorąc pod uwagę niebezpieczeństwo, jakie mogą stanowić na etapie eksploatacji badanych złączy. Ponieważ większość wskazań uzyskiwanych w badaniach TOFD w praktyce przemysłowej pochodzi od niezgodności spawalniczych o niewielkiej wysokości (np. wskazania od niewielkich przyklejeń brzegowych, międzyściegowych czy żużli, których wysokość rzadko przekracza $2 \mathrm{~mm}$ ) z tego względu konieczne jest określenie w procedurze badania jednoznacznych wymagań dotyczących oceny wskazań niemierzalnych po wysokości. Wymagania te powinny być efektem analizy rozdzielczości przestrzennej dla zastosowanej konfiguracji badawczej TOFD.

\section{Podsumowanie}

Procedura badania ultradźwiękowego techniką czasu przejścia wiązki dyfrakcyjnej TOFD powinna zawierać udokumentowaną strategię badania, zapewniającą znormalizowaną i powtarzalną metodologię badania złącza. Wymaga to zawarcia w niej - prócz typowych informacji charakterystycznych dla badań ultradźwiękowych - znacznej ilości zagadnień specyficznych dla tej techniki. Między innymi musi ona uwzględniać wpływ stref martwych przy powierzchni skanowania oraz przy powierzchni przeciwległej na wykrywalność potencjalnych niezgodności spodziewanych ze względu na zastosowaną technologię wykonania złącza. W niektórych przypadkach, zwłaszcza przy badaniu złączy o wysokiej odpowiedzialności, może to wymagać zapewnienia dodatkowego pokrycia stref martwych inną techniką badań (phased array, konwencjonalne badanie UT głowicami skośnymi). Ponadto procedura badania techniką TOFD powinna zawierać szczegółowe wytyczne dotyczące oceny wskazań niemierzalnych po wysokości, charakterystycznych dla nieciągłości o niewielkiej wysokości. Wytyczne te powinny być poprzedzone dokładną analizą wartości rozdzielczości przestrzennej wynikającej z parametrów zastosowanej konfiguracji TOFD oraz dopuszczalnych wymiarów wskazań w kierunku głębokości wynikających z przyjętego poziomu akceptacji i grubości złącza.

\section{Literatura}

[1] Mackiewicz S., Kopiński J.: Doświadczenia z zastosowań ultradźwiękowej techniki TOFD. Materiały VII Seminarium „Nieniszczące Badania Materiałów", Zakopane 14-16 marca 2001.

[2] Śliwowski M.: Badanie obwodowych złączy spawanych gazociągów zmechanizowanym systemem ultradźwiękowym TOFD+PE. XXII Naukowo-Techniczna Krajowa Konferencja Spawalnicza, Międzyzdroje, 17 $\div 19$ maja 2016.

[3] Kaczmarek R., Kaczmarek K., Słania J.: Zalety symultanicznych badań ultradźwiękowych techniką Phased Array i TOFD złączy spawanych, Przegląd Spawalnictwa, vol. 89, nr 4, 2017.

[4] Kaczmarek K., Kaczmarek R.: Problematyka oceny jakości złączy spawanych techniką TOFD w świetle aktualnych norm przedmiotowych, Biuletyn Instytutu Spawalnictwa, nr 3, 2017.

[5] Kaczmarek R., Kaczmarek K., Słania J., Krawczyk R.: Wykonywanie badań ultradźwiękowych techniką TOFD w aspekcie wymagań norm przedmiotowych, Biuletyn Instytutu Spawalnictwa, nr 4, 2016.
[6] Kaczmarek K., Irek P., Rawicki Ł., Słania J.: Wykrywanie niezgodności w złączach spawanych za pomocą techniki czasu przejścia wiązki dyfrakcyjnej (TOFD), Biuletyn Instytutu Spawalnictwa, nr 5, 2016.

[7] PN-EN ISO 10863 Badania nieniszczące spoin - Badania ultradźwiękowe - Zastosowanie techniki dyfrakcji fal ultradźwiękowych (TOFD).

[8] PN-EN ISO 16810 Badania nieniszczące - Badania ultradźwiękowe - Zasady ogólne.

[9] PN-EN ISO 15626 Badanie nieniszczące spoin - Technika czasu przejścia wiązki dyfrakcyjnej (TOFD) - Poziomy akceptacji.

[10] PN-EN ISO 16828 Badania nieniszczące - Badania ultradźwiękowe - Dyfrakcyjna technika czasu przejścia jako sposób wykrywania i wymiarowania nieciągłości. 